\title{
Alteration of Adult Erythrocyte Lipids during In Vivo Fetal Circulation
}

\author{
Robert C. NeErhout ${ }^{[44]}$ \\ Division of Hematology, Gwynne Hazen Cherry Memorial Laboratory, UCLA School of Medicine, Los Angeles, California, USA
}

\section{Extract}

The effects on membrane lipid composition of chronic in vivo exposure of adult cells to a fetal plasma environment were studied in eight infants who received repeated intrauterine transfusions for erythroblastosis fetalis. Comparison is made between the lipid composition of the transfused adult cells obtained at delivery and the lipid composition of cells from normal newborn infants, from nontransfused newborn infants with erythroblastosis (EB), and from adult donor cells. Transfused cells which had circulated in the fetus for a minimum of 5-16 days showed a significant increase in membrane cholesterol (transfused cell cholesterol : $1.53 \mathrm{mg} /$ cell $\times 10^{-10}$; donor cell cholesterol : $1.26 \mathrm{mg} /$ cell $\left.\times 10^{-10}\right)$. One patient in whom donor cells circulated a minimum of 30 days showed increased levels of total lipid $\left(6.73 \mathrm{mg} /\right.$ cell $\left.\times 10^{-10}\right)$ and lipid phosphorus $\left(1.35 \mathrm{mg} / \mathrm{cell} \times 10^{-11}\right)$ as well as cholesterol $\left(1.74 \mathrm{mg} /\right.$ cell $\left.\times 10^{-10}\right)$. These increases in membrane lipid content were not accompanied by increased cell volume.

Phospholipid distribution in cells circulating the shorter period was similar to that seen in donor cells except for a lower percentage of combined phosphatidyl serine + phosphatidyl inositol (transfused cells: $10.6 \%$ total phosphorus; donor cells: $13.5 \%$ total phosphorus). The patient with longer cell circulation had an abnormal phospholipid distribution, similar to that seen in hepatic disease (phosphatidyl choline : $44.4 \%$ total phosphorus; donor phosphatidyl choline: $28.4 \%$ total phosphorus), and subsequently developed elevated levels of direct bilirubin.

Phospholipid fatty acid distribution in the transfused cells more closely resembled the fetal pattern with low levels of linoleic acid (transfused: $5.7 \%$ of total fatty acids; donors: $10.0 \%$ of total fatty acids). Sensitivity of the transfused erythrocytes to hydrogen peroxide hemolysis was elevated in three patients (fetal cell pattern) and low in three patients (adult cell pattern). Lipid values in plasma were similar in transfused patients, in nontransfused infants with $\mathrm{EB}$, and in normal infants except for slight elevations of total phospholipid in the transfused group.

\section{Speculation}

The concept that fetal erythrocytes containing fetal hemoglobin are necessary for intrauterine life would appear untenable inasmuch as it is now apparent that adult erythrocytes with adult hemoglobin can maintain fetal viability in utero. Because many of the functional characteristics of the fetal erythrocyte are more directly related to the presence of a fetal red cell membrane than to the presence of fetal hemoglobin, it is possible that the efficacy of adult cells in utero may, in part, be related to an ability to adapt to a fetal environment. These studies demonstrate a tendency for transfused adult erythrocytes to alter certain aspects of their lipid composition when exposed to a fetal plasma environment in vivo. 


\section{Introduction}

As a result of a lack of significant de novo lipid synthesis, the exythrocyte is dependent on the plasma environment for lipid homeostasis, either by a mechanism of direct exchange or by conversion of monoacyl phospholipid in plasma to cellular phospholipid through acylation [3, 19, 20, 31, 32]. Despite this, the erythrocyte seems capable of maintaining relatively normal lipid composition in several pathologic states associated with severe plasma hyperlipemia [21]. Conversely, total lipid content of erythrocytes in cord blood is $27 \%$ higher than that found in adult erythrocytes despite circulation in a comparatively low plasma environment $[8,22]$.

It is unclear whether this dissociation between erythrocyte and plasma lipid levels in the neonate is an intrinsic characteristic of the fetal cell or whether it is a reflection of interaction between the cell and the plasma environment. The administration of adult blood in utero to the fetus affected by erythroblastosis [18] offers a unique opportunity to study the effect of chronic exposure to a fetal plasma environment on adult erythrocyte membrane lipids in vivo.

\section{Materials and Methods}

Erythrocyte lipid studies were performed on samples of cord blood from a selected group of eight infants who received multiple intrauterine transfusions for $\mathrm{Rh}$ erythroblastosis at the UCLA Medical Center (group IUT). The infants received between two and six intrauterine transfusions with an average interval of 14 days between each transfusion. The criteria for transfusion and the method utilized have been previously reported [17]. Infants were selected in whom, at birth, essentially all circulating erythrocytes were transfused adult cells (based on cell $\mathrm{ABO}$ and $\mathrm{Rh}$ type, direct Coombs' test and acid elution staining characteristics). The clinical and laboratory course of these infants is shown in Table I; on samples of cord blood from a control group of $10 \mathrm{Rh}$ infants with erythroblastosis (EB) who did not receive intrauterine transfusions to characterize the anticipated lipid patterns from residual fetal cells (group E); on samples from 15 freshly drawn type $\mathrm{O}$, $\mathrm{Rh}$-negative blood donor units to characterize the transfused adult donor cells (group $D)$; and on samples of cord blood from a group of 42 full term normal newborn infants previously reported [22] (group N).

Plasma lipid studies were performed on all patients in group IUT and group $E$ as well as on nine members from group $N$.

Blood samples were collected in ethylenediaminetetraacetic acid ( $1 \mathrm{mg} / \mathrm{ml}$ blood), centrifuged at $4^{\circ}$, and the plasma was removed. The buffy coat was discarded. Erythrocytes were washed two to three times with an equal volume of $0.9 \% \mathrm{NaCl}$ until the supernatant was clear. A $60-70 \%$ suspension of erythrocytes in $0.85 \% \mathrm{NaCl}$ was made and aliquots were taken for hematocrit determination and cell counting [40]. Erythrocyte lipid determinations on all study patients were performed in duplicate.

Two-milliliter aliquots of erythrocyte suspension or plasma were extracted twice in chloroform-methanol $(2: 1)$ by a modification of the method of Farquhar [9, 23]. Total lipid extract was dissolved in $10 \mathrm{ml}$ petroleum ether and aliquots were taken for determinations of total lipid, determined gravimetrically; total cholesterol [6]; lipid phosphorus [2]; and phospholipid fractionation employing thin layer chromatography (TLC) on Silica Gel H [33]. Lipid spots were localized by iodine vapor and identified by comparison with purified phospholipid standards. Phosphorus content of individual fractions was determined [26]. Separation of phospholipid from neutral lipid was accomplished by column chromatography on silicic acid [35]. Phospholipid fatty acids were methylated [36] and quantitated on a gas chromatograph [41] utilizing a 6-foot column packed with $15 \%$ diethylene glycol succinate liquid phase on Chromsorb $W$ (oven temperature, $180^{\circ}$; injector temperature, $280^{\circ}$; detector temperature, $210^{\circ}$ ). Fatty acids were identified by comparison with known standards [42] and published retention times [1]. Aldehydes were identified by the method of Farquhar [10].

Multiple erythrocyte analysis utilizing these procedures have the following coefficients of variation for major lipid fractions: total lipid per cell, 1.13; phosphorus per cell, 1.39; cholesterol per cell, 0.69; percentage of lipid as phosphorus, 1.04; percentage of lipid as cholesterol, 0.76 ; percentage of sphingomyelin, 1.82; percentage of phosphatidyl choline, 0.77 ; percentage of phosphatidyl serine + inositol, 2.78; percentage of phosphatidyl ethanolamine, 1.16; percentages of fatty acids-16:0 $=4.21,18: 0=3.25,18: 1$ $=2.48,18: 2=2.55,20: 4=3.27$. Recovery of phospholipid phosphorus from TLC fractionation $=96.2 \%$ of applied phosphorus.

Fetal cells were identified by the acid elution technique [16]. Hydrogen peroxide hemolysis test was per- 
Table 1 . Clinical status of study group patients who received intrauterine transfusions (IUT)

\begin{tabular}{|c|c|c|c|c|c|c|c|c|}
\hline Patient no. & 1 & 2 & 3 & 4 & 5 & 6 & 7 & 8 \\
\hline Birth weight, $g$ & 2300 & 2010 & 2800 & 2920 & 1480 & 2860 & 2780 & 1918 \\
\hline Gestation, wk & 35 & 33 & 36 & 36 & 32 & 36 & 38 & 36 \\
\hline \multicolumn{9}{|l|}{ Transfusion status } \\
\hline No. of IUT & 4 & 3 & 3 & 6 & 3 & 4 & 5 & 2 \\
\hline Total volume of IUT, $\mathrm{ml}$ & 380 & 300 & 300 & 600 & 315 & 360 & 405 & 125 \\
\hline $\begin{array}{l}\text { Interval; IUT } 1 \rightarrow \text { delivery, } \\
\text { days }\end{array}$ & 45 & 33 & 54 & 71 & 36 & 55 & 58 & 45 \\
\hline $\begin{array}{l}\text { Interval; last IUT } \rightarrow \text { de- } \\
\text { livery, days }\end{array}$ & 13 & 5 & 16 & 6 & 9 & 8 & 7 & 30 \\
\hline \multicolumn{9}{|l|}{ Cord blood studies } \\
\hline Blood type & 0 & 0 & 0 & 0 & 0 & 0 & 0 & 0 \\
\hline Rh type & Negative & Negative & Negative & Negative & Negative & Negative & Negative & Negative \\
\hline Direct Coombs' & Negative & Negative & Negative & Negative & Negative & Negative & Negative & Negative \\
\hline Fetal cells, \% & 0.5 & 2 & 4 & 0.5 & 0.5 & 1 & 0.5 & 0.5 \\
\hline Bilirubin, $\mathrm{mg} / 100 \mathrm{ml}$ & 3.4 & 5.5 & 3.7 & 3.4 & 2.6 & 2.7 & 4.8 & 8.3 \\
\hline Hematocrit, $\%$ & 42 & 42 & 40 & 50 & 38 & 48 & 31 & 25 \\
\hline Corpuscular volume, $\mu^{3}$ & 94 & 97 & 94 & 101 & 94 & 94 & 95 & 90 \\
\hline \multicolumn{9}{|l|}{ Neonatal course } \\
\hline Exchange transfusion & 0 & 2 & () & 0 & 2 & 0 & 1 & 1 \\
\hline \multicolumn{9}{|l|}{ Peak bilirubin, $\mathrm{mg} / 100 \mathrm{ml}$} \\
\hline Total & 14.4 & 21.3 & 11.3 & 6.8 & 21.6 & 14.9 & 25.9 & 14.0 \\
\hline Direct & 5.4 & 2.5 & 6.0 & 1.0 & 1.6 & 0.7 & 13.9 & 7.2 \\
\hline \multicolumn{9}{|l|}{ Outcome } \\
\hline Living & + & + & + & + & + & + & + & \\
\hline Expired & & & & & & & & + \\
\hline
\end{tabular}

formed by the method of Gordon et al. [13] modified to include use of 2,3 , and $4 \% \mathrm{H}_{2} \mathrm{O}_{2}$.

\section{Results}

Erythrocyte lipid values in $I U T$ patients $1-7$ were similar and are consequently grouped together for comparison; IUT patient $\delta$ showed dissimilar values and is listed separately. It should be noted in Table I that the interval from last transfusion to birth in $I U T$ patients $1-7$ ranged from 5 to 16 days, whereas the interval in $I U T$ patient 8 was 30 days.

The values for total lipid, lipid phosphorus, and cholesterol of the erythrocytes are shown in Figure 1. Levels of total lipid and lipid phosphorus per cell in erythrocytes from IUT patients $1-7$ were similar to those found in adult donor cells, whereas levels of cholesterol per cell were significantly higher $(P<0.01)$, and approached the levels seen in erythrocytes from normal newborn infants and infants with EB. The percentage of total lipid present as phospholipid was similar in all groups studied (IUT patients $1-7, I), N$, and $E$ ). The percentage of total lipid as cholesterol in the IUT group exceeded that of the donors and fell in the upper range for normal newborns or newborns with EB.

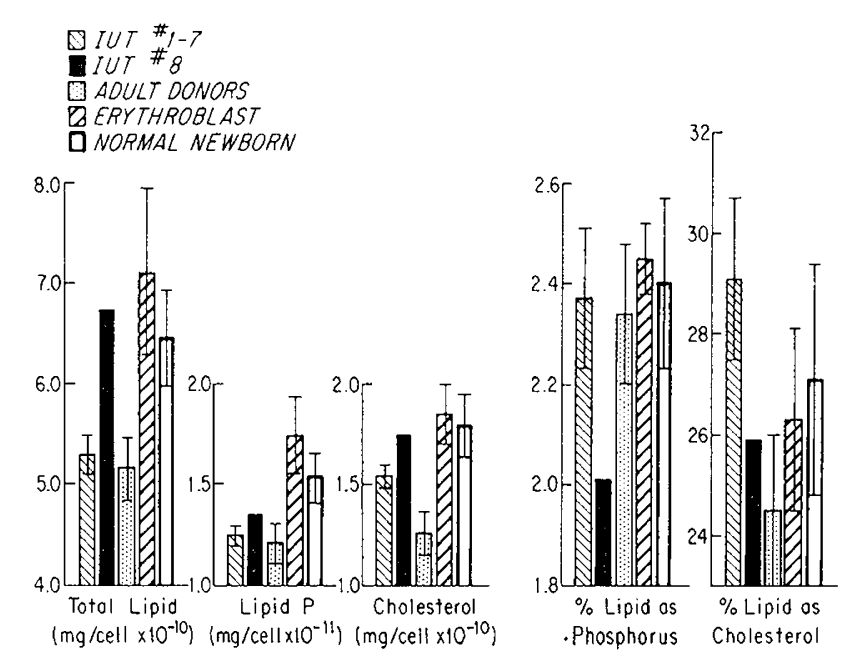

Fig. 1. Levels of total lipid, lipid phosphorus, and cholesterol per cell from erythrocyte membranes. Columns to the right show the percentage of the total lipid per cell represented by lipid phosphorus and cholesterol. Bars denote \pm I sD.

The IUT patient 8 , who had the longest interval between the last transfusion and delivery (30 days), showed values for total lipid and cholesterol per cell similar to those seen in normal infants. Lipid phosphorus per cell was at a level midway between the 


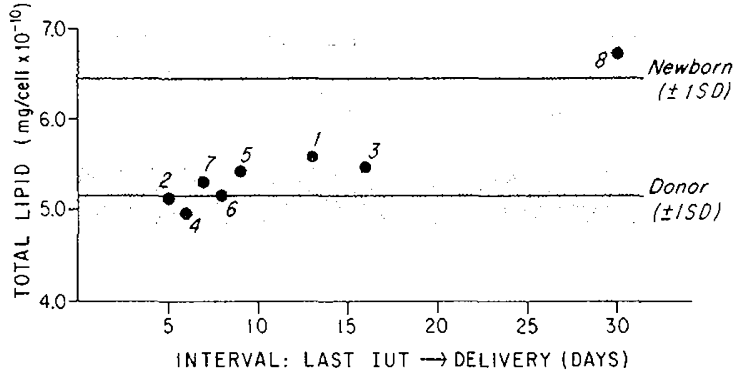

Fig. 2. Relation between the total erythrocyte membrane lipid per cell at birth and the interval between the last donor cell transfusion and delivery. Shaded areas denote mean values \pm 1 s) for total lipid per cell of donor blood and normal newborn infants. Patient numbers correspond with those in Table $Y$.

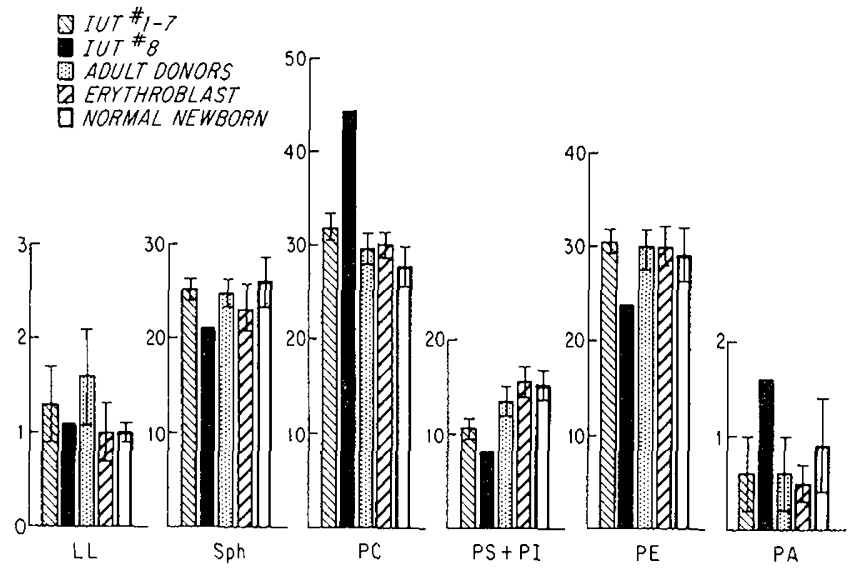

Fig. 3. Distribution of individual phosphatides expressed as percentage of total lipid phosphorus per cell. $L L$ : lysolecithin. Sph: sphingomyclin. $P C$ : phosphatidyl choline. $P S$ : phosphatidyl scrine. PI: phosphatidyl inositol. PE: phosphatidyl ethanolamine. PA: phosphatidic acid. Bars denote $\pm 1 \mathrm{sD}$.

mean for normal newborn cells and the mean for donor cells. Figure 2 shows the relation between total lipid per cell at delivery and the minimal duration of circulation of the transfused adult cells in the fetus. There is a trend toward increase in membrane lipid per cell with progressively longer exposure to the fetal environment in utero (correlation coefficient, 0.96).

Phospholipid fractionation of erythrocytes is shown in Figure 3. The percentage of phospholipid in the combined phosphatidyl serine and phosphatidyl inositol fraction of cells from IUT patients $1-7$ was significantly decreased $(P<0.01)$ when compared with percentage of phospholipid found in cells from donors, from normal newborn controls, or from infants with EB. The percentage of phosphatidyl choline in cells from IUT patients 1-7 did not differ significantly from that found in the donor group or those with EB. The level of phosphatidyl choline in cells of both $I U T$ paticnts 1-7 and controls with EB was significantly in- creased over the relatively low levels previously emphasized as characteristic of normal newborn cells $(P<$ 0.01 ) [22]. Two of the samples from IUT patients $1-7$ had phosphatidyl choline values in excess of $2 \mathrm{sD}$ above the mean for the donor cells (patient 1: $34.2 \%$; patient 7:33.4\%). Erythrocytes from four of the remaining five patients had percentages of phosphatidyl choline in excess of $31 \%$ of total lipid phosphorus.

Erythrocytes of IUT patient 8 had a phospholipid fractionation which tended to accentuate the differences noted above for IUT patients $1-7$. The percentage of phosphatidyl choline (PC) was markedly elevated (44.4\% of total lipid phosphorus) with concomitant reduction in percentages of sphingomyelin, phosphatidyl ethanolamine (PE) and combined phosphatidyl serine (PS) + inositol (PI). When calculated on the basis of milligrams $\times 10^{-13}$ of phosphorus per cell, the alterations of the relative phospholipid distribution of: IUT patient 8 can be shown to be quantitatively altered as well (IUT patient 8 : PC: 59.9; PS + PI: 10.9; PE: 32.1; donors: PC: 35.8; PS + PI: 16.3; PE: $36.3 \mathrm{mg}$ $\mathrm{P} /$ cell $\left.\times 10^{-13}\right)$. Similar alterations in phosphatidyl choline and phosphatidyl ethanolamine have previously been reported in patients with liver disease, particularly when associated with biliary obstruction [23].

Erythrocyte phospholipid fatty acid distribution is shown in Table II. Nineteen identifiable peaks have been quantitated by gas chromatography but only 10 major fatty acids are compared here. Cells from IUT patients $1-7$ differed from donor cells in having higher levels of palmitic acid $\left(\mathrm{C}_{16: 0}\right)$ and palmitoleic acid $\left(\mathrm{C}_{16: 1}\right)$ combined with lower levels of stearic acid $\left(\mathrm{C}_{18: 0}\right)$ and linoleic acid $\left(\mathrm{C}_{18: 2}\right)$. The major difference is in the lower levels of linoleic acid where IUT patients $1-7$ approached the low values characteristic of those found in cells of both normal newborns and newborn infants with EB; IUT patient 8 again showed an accentuation of the trends noted in the other $I U T$ patients. Although the levels of palmitic acid $\left(\mathrm{C}_{16: 0}\right)$, palmitoleic acid $\left(\mathrm{C}_{16: 1}\right)$, oleic acid $\left(\mathrm{C}_{18: 1}\right)$ and arachidonic acid $\left(\mathrm{C}_{20: 4}\right)$ reported were similar to those seen in normal newborns, the low level of stearic acid $\left(\mathrm{C}_{18: 0}\right)$ observed in IUT patient 8 was distinctly lower than that found in either donor cells, in cells from controls with EB, or in cells from normal newborn controls. As in IUT patients 1-7, the level of linoleic acid of IUT patient $8(6.2 \%)$ fell between the newborn level $(3.4 \%)$ and the donor level $(10.0 \%)$.

Plasma lipid values for the IUT group are contrasted with those of normal newborns and control groups with EB (Fig. 4). Plasma lipid values for $I U T$ patient 8 fell well within the range noted for IUT patients 1-7 
T'able II. Fatty acids esterified to erythrocyte membrane phospholipid ${ }^{1}$

\begin{tabular}{|c|c|c|c|c|c|c|c|c|c|c|}
\hline Subjects & $\mathrm{C}_{16: 0^{2}}$ & $\mathrm{C}_{16}: 1$ & $C_{1 s}: 0$ & $\mathrm{C}_{18: 1}$ & $C_{18: 2}$ & $\mathrm{C}_{20}: 4$ & $\mathrm{C}_{24: 0}$ & $\mathrm{C}_{24}: 1$ & $C_{22: 5}$ & $C_{22}: 6$ \\
\hline IU'T patients $1-7$ & $\begin{array}{l}20.9^{3} \\
\quad \pm 1.6^{4}\end{array}$ & $\begin{array}{l}1.6 \\
\quad \pm 0.4\end{array}$ & $\begin{array}{l}14.8 \\
\quad \pm 1.2\end{array}$ & $\begin{array}{l}16.8 \\
\quad \pm 1.5\end{array}$ & $\begin{array}{l}5.7 \\
\quad \pm 0.6\end{array}$ & $\begin{array}{l}17.9 \\
\quad \pm 0.5\end{array}$ & $\begin{array}{l}2.9 \\
\quad \pm 0.5\end{array}$ & $\begin{array}{l}2.1 \\
\quad \pm 1.2\end{array}$ & $\begin{array}{l}3.0 \\
\quad \pm 1.7\end{array}$ & $\begin{array}{l}4.9 \\
\quad \pm 1.4\end{array}$ \\
\hline IUT palient 8 & 24.6 & 1.7 & 12.4 & 13.9 & 6.2 & 20.3 & 3.2 & 1.5 & 1.2 & 4.1 \\
\hline Donor & $\begin{array}{l}18.1 \\
\quad \pm 1.4\end{array}$ & $\begin{array}{l}0.9 \\
\quad \pm 0.1\end{array}$ & $\begin{array}{l}16.7 \\
\quad \pm 1.0\end{array}$ & $\begin{array}{l}15.5 \\
\quad \pm 1.1\end{array}$ & $\begin{array}{l}10.0 \\
\quad \pm 1.5\end{array}$ & $\begin{array}{l}17.1 \\
\quad \pm 1.1\end{array}$ & $\begin{array}{l}3.3 \\
\quad \pm 0.9\end{array}$ & $\begin{array}{l}1.7 \\
\quad \pm 0.8\end{array}$ & $\begin{array}{l}2.8 \\
\quad \pm 1.2\end{array}$ & $\begin{array}{l}3.5 \\
\quad \pm 0.8\end{array}$ \\
\hline Ery throblas tosis & $\begin{array}{l}22.4 \\
\quad \pm 2.0\end{array}$ & $\begin{array}{l}1.7 \\
\quad \pm 0.3\end{array}$ & $\begin{array}{l}17.2 \\
\quad \pm 1.8\end{array}$ & $\begin{array}{l}14.3 \\
\quad \pm 1.5\end{array}$ & $\begin{array}{l}3.6 \\
\pm 0.5\end{array}$ & $\begin{array}{l}17.0 \\
\quad \pm 1.3\end{array}$ & $\begin{array}{l}4.6 \\
\quad \pm 0.7\end{array}$ & $\begin{array}{l}2.4 \\
\quad \pm 0.5\end{array}$ & $\begin{array}{l}1.3 \\
\quad \pm 1.3\end{array}$ & $\begin{array}{l}5.1 \\
\quad \pm 1.2\end{array}$ \\
\hline Normal newborn & $\begin{array}{l}21.3 \\
\quad \pm 2.4\end{array}$ & $\begin{array}{l}1.0 \\
\quad \pm 0.3\end{array}$ & $\begin{array}{l}16.3 \\
\quad \pm 1.0\end{array}$ & $\begin{array}{l}11.9 \\
\quad \pm 1.1\end{array}$ & $\begin{array}{l}3.4 \\
\quad \pm 0.6\end{array}$ & $\begin{array}{l}19.6 \\
\quad \pm 1.4\end{array}$ & $\begin{array}{l}5.5 \\
\quad \pm 1.6\end{array}$ & $\begin{array}{l}3.4 \\
\quad \pm 0.7\end{array}$ & $\begin{array}{l}0.8 \\
\quad \pm 0.9\end{array}$ & $\begin{array}{l}6.6 \\
\quad \pm 1.1\end{array}$ \\
\hline
\end{tabular}

1 Values are expressed as percent by weight of total fatty acid recovered.

${ }^{2}$ First number designates carbon chain length; second number designates double bonds. Nineteen identifiable fatty acids and aldehydes were quantitated as previously described $[22,23]$. The 10 major fatty acids are presented for comparison.

${ }^{3}$ Mcan.

${ }^{4} \pm \mathrm{sD}$.

and only the combined group values (IUT patients 1-8) are shown. Total plasma lipids and cholesterol showed no significant differences among the three groups. Levels of total phospholipid in the IUT group were significantly increased $(P<0.01)$ compared with those found in normal newborns, but not when compared with other infants with EB. Phospholipid fractionation showed no significant variations among the three groups. Phospholipid fatty acid distribution is not shown, but it was similar in all three groups with the exception of oleic acid $\left(\mathrm{C}_{18: 1}\right)$, which was significantly increased $(P<0.01)$ in both the controls with $\mathrm{EB}$ and the IUT group over the level seen in normal newborns.

Peroxide hemolysis studies on six of the infants in the IUT group are shown in Figure 5. Three of the patients $(2,4$, and 6) showed sensitivity to peroxide hemolysis similar to that normally seen with adult cells. The other three infants, 5, 7, and 8 , showed sensitivity to peroxide hemolysis similar to that seen in normal newborn cells.

\section{Discussion}

The utilization of intrauterine transfusion of adult blood into the fetus affected with erythroblastosis has afforded a unique opportunity to study the effect on adult erythrocyte lipids of chronic exposure to a fetal plasma environment in vituo. Because of the severity of the rhesus sensitization, essentially all of the infants' own Rh-positive cells had been destroyed in the infants selected. A relatively pure sample of transfused adult blood was thus available for study at birth. Previous reports on intrauterine transfusions have emphasized this phenomenon [5,29]. Since de novo lipid synthesis is virtually nonexistent in the nonnucleated erythro-
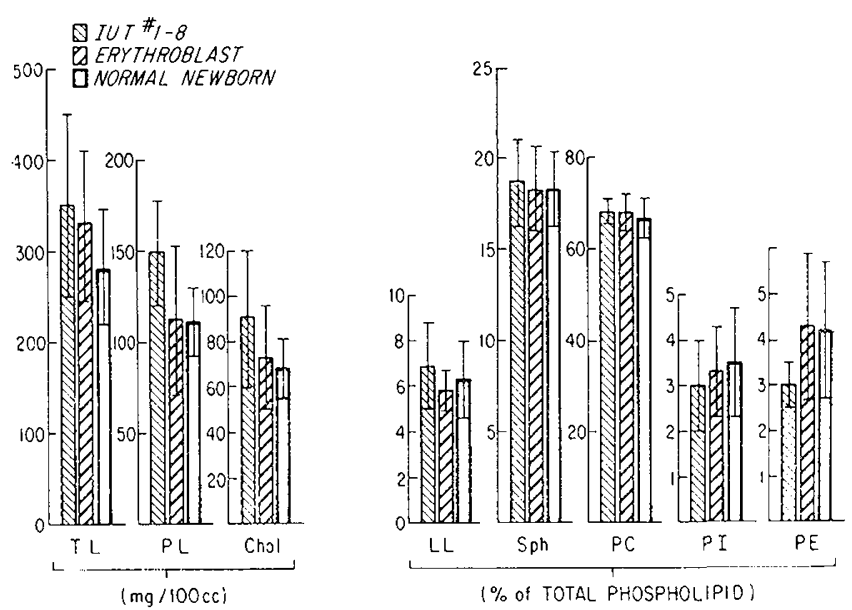

Fig. 4. Lipid distribution of plasma at delivery in the three neonatal groups. TL: total lipid. PL: total phospholipid. Chol: cholesterol. Abbreviations for phospholipids are as noted in Figure 3. Bars denote \pm 1 sD.

cyte, it is assumed that the lipid alterations noted in the cells thus obtained have occurred by a process of plasma lipid-membrane lipid interaction. Despite the low level of plasma lipid noted in the study infants, the transfused erythrocytes tended to increase the lipid content, particularly cholesterol, with increasing duration of circulation in vito. The changes noted in lipid composition of the adult erythrocytes are in the direction of that normally found in erythrocytes of normal newborns [22]. The one patient, IUT patient $s$, in whom adult cells circulated for a minimum of 30 clays, attained levels of total lipid and cholesterol in the erythrocytes comparable to those in the neonate. Since the exchange between erythrocyte and plasma cholesterol appears to have the most rapid turnover of all the membrane lipids [15], it would be anticipated that 


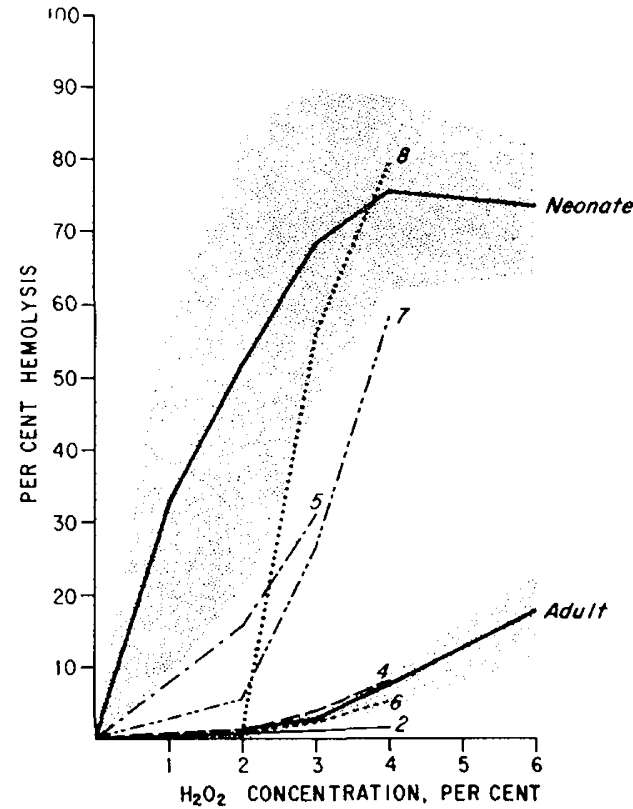

Fig. 5. Peroxide hemolysis studies at delivery of six patients who received intrauterine transfusions of adult blood. Patient numbers correspond with those in Table I. Solid line and shaded areas denote mean $\pm \mathrm{I}$ sD for normal adult and newborn control subjects.

cholesterol levels of the membranes would reflect these changes most rapidly.

This trend toward increased membrane lipid in the study group is accentuated when considered as a function of cell size. The erythrocytes of the infants with $\mathrm{EB}$ and of normal newborn controls were macrocytic compared with the donor cells (mean corpuscular volume: erythroblastotic, $192 \mu^{3}$; normal newborns, 120 $\mu^{3}$; (donor, $\left.100 \mu^{3}\right)$. Cells recovered from the IUT group were smaller than donor cells (mean corpuscular volume: IUT patients $1-7,95 \mu^{3}$; IUT patient 8,90 $\left.\mu^{3}\right)$. Although cell volume is not directly proportional to cell membrane surface area, the expression of cell lipid as a function of cell volume serves to develop a relatively consistent relation between these two variables in the age groups under question. Normal adult erythrocytes contain $5.07 \times 10^{-10} \mathrm{mg}$ lipid/100 $\mu^{3}$ volume. The donor cells are similar, with $5.14 \times 10^{-10}$ mg lipid $/ 100 \mu^{3}$. Both normal newborns and newborns with EB have $5.38 \times 10^{-10} \mathrm{mg} \operatorname{lipid} / 100 \mu^{3}$. Despite the smaller volume, adult cells recovered from $I U T$ patients $1-7$ had $5.56 \times 10^{-10} \mathrm{mg}$ lipid/100 $\mu^{3}$. The expected trend with normal cell aging would be a decreasing amount of total lipid, phospholipid, and cholesterol with decreasing cell volume [34].

The percentage of individual phosphatides found in the transfused cells at birth shows a pattern unique to this group. The low levels of combined phosphatidyl serine and phosphatidyl inositol are in marked contrast to both the donor cells and those from infants with EB or from normal newborn controls. Inasmuch as the major component of this fraction is phosphatidyl serine (which has a negligible turnover rate with plasma), this may be merely a reflection of lipid loss with cell aging [27, 37]. Previous studies, however, have not noted significant changes in phospholipid distribution with cell aging [34].

The factors which cause adult erythrocytes circulating in a fetal plasma to alter their lipid composition are not known. The lipid composition of erythrocytes from normal neonates differs from that of adult erythrocytes primarily by having an increased amount of total lipid, phospholipid, and cholesterol per cell [22]. When compared with adult erythrocytes, phospholipid distribution in neonatal erythrocytes shows lower percentages of phosphatidyl choline and phosphatidyl ethanolamine coupled with increased percentages of sphingomyelin and combined phosphatidyl serine + phosphatidyl inositol [22]. The possible in fluence of decreased plasma levels of lecithin-cholesterol acyl transferase (LCAT) on erythrocyte membrane lipid composition has been emphasized both in patients with obstructive jaundice and in patients with a congenital deficiency of this enzyme $[7,11]$. The LCAT catalyzes the transfer of one fatty acid from lecithin to unesterified cholesterol, resulting in the formation of lysolecithin and cholesterol ester [12] Despite the fact that the rate of this transacylation reaction in the neonate serum is only one-half that found in maternal serum [30], the percentage of serum cholesterol in the ester form and the percentage of serum phospholipid represented by lecithin (phosphatidyl choline) are similar in the neonate and the adult [38, 39]. Thus it would appear unlikely that the lower levels of LCAT in neonatal serum are instrumental in in fluencing the normal erythrocyte lipid pattern signifcantly. Indeed, if decreased LCAT were an important factor in the normal neonate, an increased level of erythrocyte phosphatidyl choline, rather than a decreased level, would be anticipated, as is seen in patients with obstructive jaundice or familial absence of LCAT [7, 11, 23].

The possible influence of reduced LCAT levels of fetal plasma on the transfused adult erythrocytes is open to conjecture. A trend toward higher levels of phosphatidyl choline in the IUT cells was noted when compared with that found in cells of normal newborns 
or adult donor cells. Since similar elevations of erythrocyte phosphatidyl choline were noted in the nontransfused newborns with $\mathrm{EB}$, an alternate explanation for these observations may be the influence of obstructive jaundice or hepatocellular damage in these patients. This possibility may indeed be exemplified by the observations on IUT patient 8 . As noted above, crythrocytes of this patient had $44.4 \%$ of phospholipid as phosphatidyl choline. Total bilirubin in cord blood was $8.2 \mathrm{mg} / 100 \mathrm{ml}$ (direct not done). Repeat bilirubin measurements at $9 \mathrm{hr}$ of age, following exchange transfusion at birth, recorded a total of $8.2 \mathrm{mg} / 100 \mathrm{ml}$ with $5.5 \mathrm{mg} / 100 \mathrm{ml}$ as the direct-acting type. When last checked prior to his death on day 3 , bilirubin total was $14.0 \mathrm{mg} / 100 \mathrm{ml}$ with a direct-acting fraction of $7.2 \mathrm{mg} / 100 \mathrm{ml}$. At autopsy, the liver showed marked extramedullary hematopoiesis with bile and hemosiderin pigment within the bile canaliculi and Kupffer cells. Three other infants (IUT patients 1,3 , and 7 ) also showed significant levels of direct-reacting bilirubin during the neonatal period. The phosphatidyl choline percentage of their cord blood erythrocytes was $34.2,31.9$, and $33.4 \%$, respectively. Repeat studies on IUT patient 3 at $72 \mathrm{hr}$ of age showed an increase in phosphatidyl choline to $34.2 \%$ and an increase of erythrocyte cholesterol from $1.44 \times 10^{-10} \mathrm{mg} /$ cell to $1.62 \times 10^{-10} \mathrm{mg} / \mathrm{cell}$. These observations correlated temporally with the peak of total and direct bilirubin (total: 11.3; direct: $6 \mathrm{mg} / 100 \mathrm{ml}$ ). Serial studies were performed on IUT patient 1 . At 14 days of age the phosphaticlyl choline fraction of the erythrocyte lipids constituted $45.6 \%$ of total phospholipid while cholesterol per cell was unchanged. Serum bilirubin at that time showed a total of $13.2 \mathrm{mg} / \mathrm{I} 00 \mathrm{ml}$ and a direct fraction of $6.5 \mathrm{mg} / 100 \mathrm{ml}$. When studied at 5 months of age, he was anicteric and had a normal erythrocyte lipid profile including a phosphatidyl choline fraction of $31.4 \%$ of total lipid phosphorus. Similar observations on relatively rapid changes in erythrocyte membrane lipid composition have previously been reported in association with reversible forms of hepatic clisease and elevated direct-acting bilirubin [24]. A relation between elevated conjugated bilirubin and liver necrosis in erythroblastosis fetalis has been noted, suggesting that some of the lipid changes noted may be more directly related to the hepatic status than to the age of the recipient [28]. These observations tend to emphasize that the membrane lipid composition is in a dynamic state and dependent on multiple factors affecting the fetal metabolism.

The development of an increased susceptibility to hydrogen peroxide hemolysis is a characteristic which could not be related temporally to the period of cell circulation in utero. The intervals since the last transfusion for the three patients who showed increased peroxide hemolysis were 7,9 , and 30 days, respectively, whereas those with normal adult peroxide hemolysis patterns were 5,6 , and 8 days, respectively. If one excludes $I U T$ patient 8 from consicleration, the remaining five patients (IUT 2, 4, 5, 6, and 7) in whom peroxide hemolysis studies were performed showed essentially identical lipid profiles at birth. Therefore, it is difficult to explain the fact that three of these patients had normal and two had abnormal peroxide hemolysis on the basis of any alteration of membrane lipid. Although measurement of vitamin E lcvels was not performed on these patients, it has been shown that virtually all newborns, particularly prematures, have low levels of this vitamin [14]. A direct correlation between low levels of vitamin $\mathrm{E}$ and increased susceptibility to peroxide hemolysis in the neonate has not been noted, however [25]. It is presumed that the development of susceptibility to peroxide hemolysis in these adult cells is an acquired defect, possibly associated with circulation in a vitamin E-deficient environment, as has been described in adults with malabsorption of fat-soluble vitamins [4].

\section{Summary}

The alterations observed in lipid composition of adult erythrocytes following prolonged circulation in the fetus in utero have been reported. Transfused adult erythrocytes showed a significant increase in membrane lipid, primarily cholesterol. Membrane phospholipid distribution generally remained unchanged except for those patients in whom conjugated hyperbilirubinemia was associated with increased percentage of membrane phosphatidyl choline. Fatty acids esterified to phospholipid showed low levels of linoleic acid as typically seen in the neonate. The resulting alterations of adult erythrocyte membrane lipids following prolonged circulation in the fetus would appear to be a function of both the fetal plasma environment and fetal hepatic function.

\section{References and Notes}

1. Ackman, R. G.: Structural correlation of unsaturated fatty acids through graphical comparison of gas-liquid chromatographic retention times on a polyester substrate. J. Amer. Oil Chem. Soc., 40: 558 (1963).

2. BARTIET, G. R.: Phosphorus assay in column chromatography. J. Biol. Chem., 234: 466 (1959).

3. BASFord, J. M., Glover, J., And Grten, C.: Exchange of cho- 
lestcrol between human beta-lipoproteins and erythrocytes. Biochim. Biophys. Acta, 84: 764 (1964).

4. Binder, H. J., Hertig, D. C., Hurst, V., Finch, S. C., and Spiro, H. M.: Tocopherol deficiency in man. New Engl. J. Med., 273: 1289 (1965).

5. Bowman, J. M.: Results and complications of intrauterine transfusions after birth. In: Report of the Fifty-third Ross Conference on Pediatric Research, p. 99 (Ross Laboratories, Columbus, O., 1966).

6. Chlamori, N., and Henry, R. J.: Study of the ferric chloride method for detcrmination of total cholesterol and cholesterol esters. Amer. J. Clin. Path., 31: 305 (1959).

7. CoOper, R. A., AND JANDL, J. H.: Bile salts and cholesterol in the pathogenesis of target cells in obstructive jaundice. J. Clin. Invest., 47: 809 (1968).

8. Crowley, J., Ways, P., and Jones, J. W.: Human fetal crythrocyte and plasma lipids. J. Clin. Invest., 44: 989 (1963).

9. FarQuhar, J. W.: Human erythrocyte phosphoglyccrides. I. Quantification of plasmalogens, fatty acids and fatty aldehydes. Biochim. Biophys. Acta, 60: 80 (1962).

10. Farquhar, J. W.: Identification and gas-liquid chromatographic behavior of plasmalogen aldehydes and their acetal, alcohol and acetylated alcohol derivatives. J. Lipid Res., 3: 21 (1962).

11. (jone, E., Torsvik, J., AND Norcm, K. R.: Familial plasma cholesterol ester deficiency. A study of the erythrocytes. Scand J. Clin. Lab. Invest., 21: 327 (1968).

12. Glomset, J. A.: The plasma lecithin: cholesterol acyltransferase reaction. J. Lipid Res., 9: 155 (1968).

13. Gordon, H. H., Nirowsky, H. M., AND Cornblath, M. Studies of tocopherol deficiency in infants and children. I. Hemolysis of erythrocytes in hydrogen peroxide. Amcr. J. Dis. Child., 90: 669 (1955).

14. Gyorgy, P., Cogan, G., and Rose, C. S.: Availability of vitamin $E$ in newborn infants. Proc. Soc. Exp. Biol. Med. $81: 536$ (1952).

15. Hagerman, J. S., AND Gould, R. G.: The in vitro interchange of cholesterol between plasma and red cells. Proc. Soc. Exp. Biol. Med., 78: 329 (1951).

16. Kleihauer, E., Braun, H., and Betke, K.: Demonstration von Fetalem Hamoglobin in den Erythrocyten eines Blutausstrichs. Klin. Wochenschr., 35: 637 (1957).

17. Lecky, J. W., Bashore, R. A., Tobin, P. A., and Hanafee, W. N.: Percutaneous intrauterine fetal transfusion. Roentgenologic aspects and results. Amer. J. Roentgenol. 103: 186 (1968).

18. LiLEY, A. W.: Intrauterine transfusion of foetus in haemolytic disease. Brit. Med. J., 2: 1107 (1963).

19. Marks, P. A., Gellhorn, A., And Kidson, C.: Lipid synthesis in human leukocytes, platelets and erythrocytes. J. Biol. Chem., 235: 2579 (1960)

20. Mulder, E., and VAn Deenen, L. L. M.: Metabolism of red cell lipids: I. Incorporation in vitro of fatty acids into phospholipids from mature erythrocytes. Biochim. Biophys. Acta, 106: 106 (1965)

21. Neerhout, R. C.: Erythrocyte stromal lipids in hyperlipemic states. J. Lab. Clin. Med., 71: 448 (1968).

22. Neerhout, R. C.: Erythrocyte lipids in the neonate. Pediat Res., 2: 172 (1968).

23. NeERhout, R. C.: Abnormalities of erythrocyte stromal lipids in hepatic disease. J. Lab. Clin. Med., 71: 438 (1968).
24. Neerhout, R. C.: Reversibility of the erythrocyte lipid ab normalities in hepatic disease. J. Pediat., 73: 364 (1968).

25. Nitowsky, H. M., Cornblath, M., and Gordon, H. H.: Studies of tocopherol dcficiency in infants and children. II. Plasma tocopherol and erythrocyte hemolysis in hydrogen peroxide. Amer. J. Dis. Child., 92: 164 (1956).

26. Parker, F., AND Peterson, N. F.: Quantitative analysis of phospholipids and phospholipid fatty acids from silica gel thin-layer chromatography. J. Lipid Res., 6: 455 (1965).

27. Reed, C. F., Murphy, M., and Roberts, G.: Phospholipid exchange between plasma and erythrocytes in man and the dog. J. Clin. Invest., 47: 749 (1968).

28. Reiquam, C. W., Beatry, E. C., and Connell, J. R.: Erythroblastosis fetalis: elevated conjugated bilirubin, anemia and liver necrosis-relationships and clinical implications. Cliu. Pediat., 6: 411 (1967).

29. Reiquam, C. W., AND Butterfield, L. J.: Hematologic studies in three infants following intrauterine transfusions for erythroblastosis fetalis. Pediat. Dig., 9: 81 (1967).

30. Robertson, A. F., Sprecher, H., and Dobbs, C.: Metabolism of cholesterol esters in the human placenta. Biol. Neonatorum, 14: 32 (1969).

31. Sakagami, T., Minari, O., and ORIr, T.: Interaction of individual phospholipids between rat plasma and erythrocytes. Biochim. Biophys. Acta, 98: 356 (1965).

32. Shohet, S. B., Nathan, D. G., and Karnovsky, M. L.: Stages in the incorporation of fatty acids into red blood cells. J. Clin. Invest., 47: 1096 (1968).

33. Skipski, V. P., Peterson, R. F., AND BARCLAY, M.: Separation of phosphatidyl ethanolamine, phosphatidyl serine and other phospholipids by thin layer chromatography. J. I.ipid Res., 3: 467 (1962).

34. Van Gastel, C., Van den Berg, D., de Gier, J., and Van DEENEN, L. L. M.: Some lipid characteristics of normal red blood cells of different age. Brit. J. Haematol., 11: 193 (1965).

35. Ways, P., and Hanahan, D. J.: Characterization and quantification of red cell lipids in normal man. J. Lipid Res., 5: 318 (1964).

36. Ways, P., Reed, C. F., and Hanahan, D. J.: Red cell and plasma lipids in acanthocytosis. J. Clin. Invest. 42: 1248 (1963).

37. WeEd, R. I., AND Rerd, C. F.: Membrane alterations lcading to red cell destruction. Amcr. J. Med., 41: 681 (1966).

38. 7er, P.: Lipid metabolism in the newborn. I. Phospholipids in cord and maternal sera. Pediatrics, 39: 82 (1967).

39. ZEE, P.: Lipid metabolism in the newborn. II. Neutral lipids. Pediatrics, 41: 640 (1968)

40. Coulter model B electronic cell counter, Coulter Elcctronics, Industrial Division, Hialeab, Fla.

4l. Perkin-Elmer model 810, Perkin-Elmer Corporation, South Pasadena, Fla.

42. Applied Science Laboratories, Inc., State College, $\mathrm{Pa}$.

43. Supported by Public Health Service Research Grant no. 1-R01-HD-2124 and by the Robert Shaw Memorial Research liund.

44. Requests for reprints should be addressed to: RoBrRT C. Neerhout, M.D., Division of Hematology, Gwynne Hazen Cherry Memorial Laboratory, UCLA School of Medicine, Los Angeles, Calif. 90024 (USA).

45. Accoptcd for publication January 27, 1971. 